\title{
Pengaruh Motivasi terhadap Kinerja Karyawan pada Toko Tugu Elektronik Jambi
}

\author{
Azizah \\ Fakultas Ekonomi, Universitas Batanghari Jambi \\ Correspondence email: azizah.3007@yahoo.com
}

\begin{abstract}
Stores an electronic Monument Jambi aims specifically carry out the process of buying and selling electronic goods to the general public. Stores an electronic Monument Jambi consists of Chairman, cashier, sales, warehouse and employee sections. Simple linear regression equation using SPSS 20 retrieved data equation $y=7.057+1,061 X$. The coefficient of correlation between motivation on performance $(X)(Y)$ is $44.2 \%$ pales $r>0$ has occurred positive linear relationship. The results of hypothesis testing then the retrieved value (determination) $=r^{2}$ of 0.196 figures stated that the motivation was able to explain variable variable performance of $19.6 \%$ on the contrary $80.4 \%$ by other outside variable variables researched. Employee performance and motivation of working in a store an electronic Monument Jambi high. The leadership can provide motivation to employees of the store an electronic Monument Jambi to improve the performance of employees considering the existence of considerable influence among the motivation and performance of employees, and encourage employees to be able to demonstrate the ability himself in a job better and the leadership should be able to also appreciate the work of employees who have done well.
\end{abstract}

Keyword: motivation; performance; public

\section{PENDAHULUAN}

Sumber daya manusia merupakan salah satu faktor penting di dalammenjalankan kegiatan perusahaan. Keberhasilan suatu perusahaan sangat tergantung pada kemampuan sumber daya manusia dalam organisasi tersebut.Sumber daya manusia merupakan satu-satunya sumber daya yang memiliki akal, perasaan, keinginan, keterampilan, pengetahuan, dorongan, daya dan karya.Semua potensi sumber daya manusia tersebut berpengaruh terhadap upaya organisasi dalam mencapai tujuan. Menurut Sutrisno (2009) Betapa majunya teknologi, perkembangan informasi, tersedianya modal dan memadainya bahan, jika tanpa sumber daya manusia sulit bagi organisasi tersebut untuk mencapai tujuannya.Menurut Nawawi (2011:40) Sumber daya manusia adalah potensi manusiawi sebagai penggerak organisasi daya mewujudkan eksistensinya. Menurut Hariandja (2007) perencanaan sumber daya manusia merupakan proses penentuan kebutuhan pegawai pada masa yang akan datang berdasarkan perubahan-perubahan yang terjadi dan persediaan tenaga kerja yang ada.

Karyawan yang memiliki semangat kerja yang tinggi akan meningkatkan kehidupan organisasi atau perusahaan. Loyalitas dan semangat kerja dapat dilihat dari mereka merasa senang dengan pekerjaannya.Mengingat pentingnya faktor sumber daya manusia di dalam suatu perusahaan atau instansi maka tenaga kerja harus di perhatikan potensi sedemikian rupa, sehingga dapat di manfaatkan seoptimal mungkin agar dapat berdaya guna.Pimpinan harus memberikan lebih banyak perhatian kepada karyawan sehingga dapat memmotivasi mereka bekerja dan dapat meningkatkan imajinasi dan keterampilan dalam pekerjaannya. Menurut Mangkunegara (2017) Motivasi merupakan kondisi atau energi yang menggerakan diri karyawan yang terarah atau tertuju untuk mencapai kinerja maksimal. Kemampuan tanpa dimotivasi tidak akan menghasilkan sesuatu, akan tetapi walaupun kemampuan kurang, kalau dimotivasi pasti akan menghasilkan kinerja yang akan lebih baik dan berguna. Menurut Pinder, dalam Donovan (2001) diterjemahkan secara bebas, Motivasi adalah sekelompok pendorong yang mempunyai ciri-ciri: (1) berasal baik dari dalam maupun dari luar individu; (2) dapat menimbulkan perilaku bekerja; dan (3) dapat menentukan bentuk, tujuan, intensitas, dan lamanya perilaku bekerja.

Kondisi yang dapat menimbulkan motivasi kerja adalah karena adanya kebutuhan yang harus dipenuhi untuk memenuhi tuntutan hidup, sehingga seseorang dapat menampilkan perilaku kerja dengan baik.Kebutuhan tersebut berasal dari dalam pekerjaan itu sendiri maupun dari luar pekerjaan.Untuk dapat meningkatkan motivasi kerja maka dibutuhkan kondisi yang mendukung sehingga kondisi tersebut menjadi dorongan untuk mengoptimalkan pekerjaan. Menurut Mangkunegara (2017) kinerja adalah hasil kerja secara kualitas dan kuantitas yang dicapai oleh seorang pegawai dalam melaksanakan tugasnya sesuai dengan tanggung jawab yang diberikan kepadanya. Kinerja seseorang merupakan kombinasi dari kemampuan, usaha dan kesempatan yang dapat dinilai dari hasil kerjanya.

Toko Tugu Elektronik Jambi merupakan salah satu usaha yang bergerak di bidang penjualan barang-barang elektronik untuk masyarakat umum,yang beralamat di Tugu Juang dan memiliki cabang di Simpang IV Sipin Kota Jambi, saat ini TokoTugu Elektronik Jambi sedang menuju sebagai pusat Elektronikmodern terbesar di Jambi. Toko 
Tugu Elektronikmenjual berbagaijenis barang elektronik, seperti kulkas, televisi, mesin cuci, AC, dispenser, dan peralatan elektronik rumah tangga. Adapun jumlah karyawan Toko Tugu Elektronik Jambi sebagai berikut :

Tabel 1

Jumlah Karyawan Toko Tugu Elektronik Jambi Tahun 2014-2018

\begin{tabular}{crr}
\hline Tahun & Jumlah karyawan (orang) & PersentasePerkembangan karyawan (\%) \\
\hline 2014 & 25 & - \\
2015 & 29 & 16 \\
2016 & 35 & 20,6 \\
2017 & 31 & $(11,4)$ \\
2018 & 31 & 0 \\
\hline
\end{tabular}

Sumber: Toko Tugu Elektronik Jambi. (Tahun 2019)

Tabel 1 diatas terlihat bahwa jumlah karyawan toko Tugu Elektronik Jambi mengalami peningkatan yaitu pada tahun 2014 sampai 2015, akan tetapi pada tahun 2016-2018 mengalami penurunan. Diharapkan dengan penurunan jumlah karyawan pada Toko Tugu Elektronik tidak akan berpengaruh terhadap motivasi karyawan karenafaktor motivasi memainkan peranan yang sangat penting dalam keseluruhan upaya untuk meningkatkan kinerja, baik pada tingkat kelompok maupun pada tingkat organisasi. Dikatakan demikian karena kinerja tidak hanya menyoroti pada sudut pelaksana yang pada umumnya bersifat teknis akan tetapi juga dari kelompok kerja dan manajerial.Adapun target dan realisasi penjualan pada Toko Tugu Elektronik Jambi dalam periode 2014-2018 sebagai berikut:

Tabel 2

Rekapitulasi Target dan Realisasi Penjualan Toko Tugu Elektronik Jambi Tahun 2014-2018

\begin{tabular}{llrrrrr}
\hline \multirow{2}{*}{ No } & \multicolumn{1}{c}{ Nama Barang } & $\mathbf{2 0 1 4}$ & $\mathbf{2 0 1 5}$ & $\begin{array}{c}\text { Tahun } \\
\mathbf{2 0 1 6}\end{array}$ & $\mathbf{2 0 1 7}$ & $\mathbf{2 0 1 8}$ \\
\hline 1 & Televisi & 15 & 12 & 17 & 20 & 23 \\
2 & Kulkas & 10 & 10 & 12 & 9 & 11 \\
3 & AC & 20 & 18 & 25 & 19 & 22 \\
4 & Kompor Gas & 10 & 10 & 9 & 15 & 17 \\
5 & Selang Gas & 25 & 25 & 27 & 30 & 23 \\
6 & Kipas Angin & 12 & 12 & 10 & 13 & 19 \\
7 & Rice Cooker & 9 & 9 & 11 & 13 & 16 \\
8 & Mesin Cuci & 9 & 9 & 11 & 16 & 14 \\
9 & Speaker & 5 & 5 & 3 & 12 & 8 \\
Realisasi & 115 & 110 & 125 & 147 & 153 \\
Target & 120 & 130 & 140 & 150 & 160 \\
Kinerja (\%) & 95,83 & 84,62 & 89,29 & 98,00 & 95,63 \\
\hline
\end{tabular}

Sumber: Toko Tugu Elektronik Jambi, Tahun 2019

Tabel 2 diatas diketahui bahwa dalam lima tahun terakhir yaitu tahun 2014-2018 penjualan toko Tugu Elektronik Jambi mengalami peningkatan akan tetapi realisasi penjualan pertahun belum mencapai target yang diinginkan. Tujuan penelitianini secara adalah untuk mengetahui pengaruh disiplin terhadap kinerja Paramedis.

\section{Tinjauan pustaka}

Hasibuan (2009) mendifinisikan manajemen sumber daya manusia adalah membantu terwujudnya tujuan perusahaan, karyawan dan masyarakat. Simamora (2007) manajeman sumber daya manusia adalahpendayagunaan, pengembangan, penilaian, pemberian balas jasa dan pengelolahan individu anggota organisasi atau kelompok lainnya. Menurut Sedarmayanti (2009) manajemen sumber daya manusia adalah seni untuk merencanakan, mengorganisasikan, mengarahkan, mengawasi kegiatan sumber daya manusia atau pegawai, dalam rangka mencapai tujuan organisasi. Mangkunegara (2017) Motivasi merupakan kondisi atau energi yang menggerakan diri karyawan yang terarah atau tertuju untuk mencapai kinerja maksimal. Sedanga kan menurut Robbins dan Judge (2008) mendefinisikan motivasi sebagai proses yang menjelaskan insentitas, arah dan ketekunan seseorang individu untuk mencapai tujuannya. Sedangkan menurut Wibowo (2012), motivasi merupakan dorongan terhadap serangkaian proses perilaku manusia pada pencapaian tujuan. Sedangkan elemen yang terkandung dalam motivasi meliputi unsur membangkitkan, mengarahkan, menjaga, menunjukkan intensitas, bersifat terus-menerus dan adanya tujuan. Sedarmayanti (2009) menyebutkan ada 6 faktor motivasi yaitu: (1) prestasi :Motivasi karyawan dalam bekerja adalah selalu berusaha untuk terus meningkatkan prestasi dan memiliki tekad untuk mencapai prestasi yang terbaik; (2) pengakuan :Pengakuan yang dihadapkan karyawan dalam bekerja erat kaitannya dengan mengharapkan adanya penghargaan dari pimpinan, keinginan untuk menunjukkan kemampuan diri serta mengharapkan balas jasa yang 
sesuai; (3) kemajuan kenaikan pangkat :Melaksanakan pekerjaan karena keinginan untuk mencapai karir yang lebih baik serta menunjukkan seberapa besar tekad untuk mewujudkannya; (4) pekerjaan itu sendiri :Karyawan dapat termotivasi bekerja karena pekerjaan itu sendiri sesuai dengan keinginan dan harapannya serta sifat pekerjaan yang menantang; (5) kemungkinan untuk tumbuh :Motivasi seseorang dalam melaksanakan pekerjaan karena adanya keinginan untuk terus mengembangkan diri serta meningkatkan wawasan; dan (6) tanggung jawab :Motivasi seseorang untuk mengerjakan pekerjaan erat kaitannya dengan keinginan mereka untuk melaksanakan tanggung jawab tersebut serta tingkat komitmen untuk melaksanakan pekerjaan.

Menurut Mangkunegara (2017) kinerja adalah hasil kerja secara kualitas dan kuantitas yang dicapai oleh seorang pegawai dalam melaksanakan tugasnya sesuai dengan tanggung jawab yang diberikan kepadanya sedangkan menurut Wibowo (2012) Kinerja adalah tentang melakukan pekerjaan dan hasil yang dicapai dari pekerjaan tersebut, tentang apa yang dikerjakan dan bagaimana cara mengerjakannya. Faktor-faktor yang mempengaruhi kinerja menurut (Robbins, 1996) adalah: (a) kemampuan; (b) motivasi; dan (c) kesempatan. Menurut model partner - lawyer yang dikutip Rivai (Gibson dan Ivancevich:1994) kinerja individu pada dasarnya dipengaruhi oleh faktor-faktor : (a) harapan mengenai imbalan; (b) dorongan; (c) kemampuan, kebutuhan dan sifat; (d) persepsi terhadap tugas; (e) imbalan internal dan eksternal; dan (f) persepsi terhadap imbalan dan kepuasan kerja

Hipotesis penelitian ini adalah diduga motivasi dan kinerja karyawan pada toko Tugu Elektronik Jambi cukup tinggi.

\section{METODE}

Adapun persamaan regresi linier sederhana yang digunakan, menurut J. Supranto (2015) adalah sebagai berikut: $\mathrm{Y}=a+b X+e$; dimana : $\mathrm{Y}=$ kinerja karyawan; $\mathrm{X}=$ motivasi; $a=$ konstanta; dan $\mathrm{e}=$ Error. Uji $\mathrm{t}$ adalah pengujian koefisien regresi yang digunakan untuk mengetahui apakah variabel indepenen $(\mathrm{X})$ secara individual mempengaruhi variabel dependen (Y).

\section{HASIL}

Tabel 3

Coefficients

\begin{tabular}{|c|c|c|c|c|c|c|}
\hline \multirow{2}{*}{\multicolumn{2}{|c|}{ Model }} & \multicolumn{2}{|c|}{ Unstandardized Coefficients } & \multirow{2}{*}{$\frac{\text { Standardized Coefficients }}{\text { Beta }}$} & \multirow{2}{*}{$\mathrm{t}$} & \multirow{2}{*}{ Sig. } \\
\hline & & $\mathrm{B}$ & Std. Error & & & \\
\hline \multirow{2}{*}{1} & (Constant) & 7,057 & 20,900 & & ,338 & ,738 \\
\hline & Motivasi & 1,061 & 400 & ,442 & 2,655 & 013 \\
\hline
\end{tabular}

Sumber: data olahan

Tabel 3 diatas, maka diperoleh data persamaan regresi linear sederhana sebagai berikut:

$\mathrm{Y}=7,057+1,061 \mathrm{X}+\mathrm{e}$

Konstanta sebesar 7,057 artinya jika variabel X konstant maka kinerja karyawan senilai 7,057.Koefisien regnesi kinerja sebesar 1,061 artinya terdapat pengaruh positif antara motivasi kerja terhadap kinerja karyawan pada Toko Tugu Elektronik Jambi. Koefisien regresi motivasi karyawan sebesar 1,061 artinya jika tingkat motivasi kerja karyawan mengalami kenaikan 1\%, maka kinerja karyawan pada Toko Tugu Elektronik Jambi akan mengalami peningkatan 1,061\%. Hasil perhitungan SPSS (Statistical Package for the Social Sciences) untuk melihat koefisien korelasi dan determinasi dapat dilihat pada model summary sebagai berikut :

Tabel 4

Model Summary

\begin{tabular}{|c|c|c|c|c|}
\hline Model & $\mathrm{R}$ & R Square & Adjusted R Square & Std. Error of the Estimate \\
\hline 1 & $442^{\mathrm{a}}$ & , 196 & 168 & 11,87310 \\
\hline
\end{tabular}

Sumber: data olahan

Koefisien korelasi sebesar 0,442 artinya terdapat hubungan yang cukup erat antara variabel motivasi terhadap kinerja karyawan toko Tugu Elektronik Jambi yaitu sebesar 44,2\%. Sedangan nilai R Square sebasar 0,196 artinya pengaruh variabel motivasi terhadap kinerja karyawan toko Tugu Elektronik Jambi sebesar 19,6\% sedangkan 80,4\% dipengaruhi oleh variabel lain di luar variabel yang di teliti, seperti : kompensasi, kepemimpinan, lingkungan kerja. Berdasarkan tabel 3 diatas diperoleh angka $t_{\text {hitung }}$ sebesar $=2,655$ sedangkan $t_{\text {tabel }}$ sebesar $=2,045$. Apabila $t_{\text {hitung }}>t_{\text {tabel }}$ maka keputusan $\mathrm{H}_{0}$ ditolak $\mathrm{H}_{1}$ diterima. Dengan demikian terdapat pengaruh yang signifikan antara motivasi terhadap kinerja karyawan pada Toko Tugu Elektronik Jambi. 


\section{SIMPULAN}

Terdapat hubungan yang cukup erat antara variabel motivasi terhadap kinerja karyawan toko Tugu Elektronik Jambi yaitu nilai korelasi sebesar 0,442 atau 44,2\%. Sedangan nilai R Square sebasar 0,196 artinya pengaruh variabel motivasi terhadap kinerja karyawan toko Tugu Elektronik Jambi sebesar 19,6\% sedangkan 80,4\% dipengaruhi oleh variabel lain di luar variabel yang diteliti, seperti : kompensasi, kepemimpinan, lingkungan kerja. Berdasarkan hasil perhitungan diperoleh angka $t_{\text {hitung }}$ sebesar $=2,655$ sedangkan $t_{\text {tabel }}$ sebesar $=2,045$. Jadi $t_{\text {hitung }}>t_{\text {tabel }}$ maka keputusan $\mathrm{H}_{0}$ ditolak $\mathrm{H}_{1}$ diterima. Dengan demikian terdapat pengaruh yang signifikan antara motivasi terhadap kinerja karyawan pada Toko Tugu Elektronik Jambi.

\section{DAFTAR PUSTAKA}

Bangun, Wilson, 2012, ManajemenSumberDayaManusia, Erlangga, Jakarta

Hasibuan, Malayu SP, 2009, ManajemenSumberDayaManusia, PenerbitBumiAksara, Jakarta.

Handoko, T, Hani, 2012, Manajemen Personalia dan Sumber Daya Manusia, BPFE, Yogyakarta

Kirom, 2012, Sumber Daya Manusia, Penerbit Bumi Aksara, Jakarta

Mangkunegara, Anwar Prabu. 2006, Evaluasi Kinerja, PT. Refika Aditama Bandung.

Nawawi, Hadari, 2011, Manajemen Sumber Daya Manusia, Gajah Mada University Press, Yogyakarta

Riduan. 2008. Skala Pengukuran Variabel-variabel Penelitian. Bandung.CV. Alfabeta.

Rosidah, 2009, Manajemen Sumber Daya Manusia, GramediaPustakaUtama, Jakarta.

Saydam, Gouzali, Drs, Bc.TT, 2005, Manajemen Sumber Daya Manusia,Cet.3, Jakarta.Djambatan.

Simamora, Henry, 2006, Manajemen Sumber Daya Manusia, Edisi III, Bagian penerbitan Skolah Tinggi Ilmu Ekonomi, YKPN, Aditya Media

Sudjana, 2006. Metode Penelitian Statistika. Bandung. PustakaSetia.

Sugiono. Prof. Dr. 2011, Metode Penelitian Kuantitatif Kualitatif dan $R \& D$, Edisi 1. Bandung. Alfabeta

Supranto, 2015, Statistik Teori dan Aplikasi, Edisi Ketujuh, Jakarta, Erlangga.

Suyoto, Danang, 2013, Perilaku Organisasi, CAPS (Center for Academic Publishing Sevice,) Yogyakarta

Sedarmayanti, 2009, Sumber Daya Manusia dan Produktivitas Kerja, CV Mandar Maju

Umar, Husein, 20013, Riset Sumber Daya Manusia, GramediaPustakaUtama, Jakarta. 